Article

\title{
Response of Vegetables to Cadmium-Enriched Soil
}

Babak Ebrazi Bakhshayesh ${ }^{1}$, Madjid Delkash ${ }^{1}$ and Miklas Scholz ${ }^{2, *}$

1 Department of Civil and Environmental Engineering, University of Delaware, Newark, DE 19716, USA; E-Mails: babakeb@udel.edu (B.E.B.); delkash@udel.edu (M.D.)

2 Civil Engineering Research Group, School of Computing, Science and Engineering, The University of Salford, Newton Building, Salford M5 4WT, England, UK

* Author to whom correspondence should be addressed; E-Mail: m.scholz@salford.ac.uk; Tel.: +44-161-295-5921; Fax: +44-161-295-5575.

Received: 13 January 2014; in revised form: 29 April 2014 / Accepted: 29 April 2014 /

Published: 7 May 2014

\begin{abstract}
Environmental and water pollution through heavy metals is a growing concern. The recycling of untreated wastewater, which is often contaminated with heavy metals, for agricultural applications is becoming more popular. However, information on the amount of absorption and accumulation of cadmium $(\mathrm{Cd})$ at variable concentrations by different crops is limited. This study aims to analyze the impact of various Cd concentrations $(0,30$, 60 and $120 \mathrm{mg} / \mathrm{kg}$ ) in the root zone on the quantity of its absorption as well as accumulation in various parts of seven different types of common vegetables. The experiments were carried out under laboratory-like controlled conditions. Four treatments and three replicates were selected. Cadmium accumulation exceeded the permissible limits for human consumption, and its accumulation in different plant parts followed this order: Leaves: broccoli $>$ spinach $>$ basil $>$ garlic $>$ carrot $>$ tarragon $>$ dill. Stems: broccoli $>$ spinach $>$ basil $>$ garlic $>$ tarragon $>$ carrot $>$ dill. Roots: broccoli $>$ garlic $>$ basil $>$ spinach $>$ carrot $>$ dill $>$ tarragon. Therefore, the authors recommend the reuse of treated wastewater, which should be virtually free of contaminants such as heavy metals, to irrigate farm lands in the future.
\end{abstract}

Keywords: basil; broccoli; cadmium; carrot; garlic; irrigation; metal accumulation; spinach; tarragon; treated wastewater 


\section{Introduction}

An increase in the rate of population growth and changing water usage patterns have led to the production of high volumes of wastewater and depleting freshwater resources. Reusing wastewater can be considered as a potential solution to save freshwater resources for drinking consumption and getting rid of wastewater at the same time. One of the sectors in which non-conventional water resources are recycled is the agricultural sector. However, there are concerns regarding public health and environmental pollution as well as cultural and religious barriers hindering the widespread use of wastewater for irrigation purposes [1,2].

Irrigating agricultural farm land provides food for humans, alleviating poverty [3]. Artificial irrigation is associated with the lion share of water consumption in some regions of the world such as the Middle East and Northern Africa [1,2,4]. Despite intense droughts in some regions, about $67 \%$ to $90 \%$ of water resources are allocated to agricultural practices [5]. The reuse of wastewater in irrigation systems seems a promising method to provide the essential need for the agricultural industry. In addition to resolving the water shortage problem, irrigating with nutrient-rich wastewater provides free fertilizer to potentially poor soil. However, long-term usage of wastewater, which is mainly prevalent for cultivation of leafy vegetables, has resulted in relatively high heavy metal (e.g., Cd) accumulation in the soil and their subsequent transfer to the crops under cultivation [6,7].

Cadmium is used widely in industry; colour pigment, nickel-cadmium battery, anticorrosive agent, stabilizer in plastics. Unfortunately, the consumption of this potentially dangerous metal is increasing in developing countries such as Iran, because people often discharge this pollutant into the wastewater stream carelessly. Cadmium is often associated with fine clay particles within the raw water. The current concentration of $\mathrm{Cd}$ in wastewater received by the wastewater treatment plant of Tehran is comparatively elevated, and varies between 0.05 and $0.018 \mathrm{mg} / \mathrm{L}$ [8].

Taking appropriate measures to prevent $\mathrm{Cd}$ accumulation in the environment seems vital, because $\mathrm{Cd}$ may be easily absorbed by some plants used for human consumption and accumulates in agricultural products in concentrations that can even be considered toxic for some plant species. Excessive accumulation of $\mathrm{Cd}$ in soil can reduce the growth of plants [9]. The consumption of vegetables containing accumulated $\mathrm{Cd}$ is a known pathway for the entry of toxic metals into humans. Contaminated food can deplete some essential nutrients in the body. This could result in reduced immunological defence and some disabilities associated with malnutrition [10].

Several studies have been undertaken concerning the impact of wastewater containing Cd used for irrigation on plants and particularly vegetables in the south of Tehran (Iran). Table 1 indicates corresponding bioaccumulation findings for different plants [11]. Other vegetables such as broccoli, basil, garlic, tarragon, carrot and dill have not been studied with respect to their tolerance to $\mathrm{Cd}$. Cadmium contamination levels in farm lands are fairly high; for example, between 0.01 and $7.54 \mathrm{mg} / \mathrm{kg}$ for soil and between 0.398 and $1.437 \mathrm{mg} / \mathrm{kg}$ dry weight for the corresponding crops growing on the contaminated soil south of Tehran [12].

Introducing $\mathrm{Cd}$ to soil by irrigation with wastewater containing $\mathrm{Cd}$ enhances the level of $\mathrm{Cd}$ in the corresponding topsoil. It follows that there is a need to assess the responses of different vegetables and their individual parts to $\mathrm{Cd}$ bioaccumulation to prevent humans eating vegetable parts that are too contaminated. Furthermore, the most Cd-tolerant vegetable should be promoted for further cultivation. 
Table 1. Cadmium bioaccumulation in plant parts for a relevant case study south of Tehran, Iran [11].

\begin{tabular}{ccc}
\hline Plant & Part & Concentration (ppm) \\
\hline Corn & Seed & 3.22 \\
Alfalfa & Shoot & 4.9 \\
Lettuce & Leaf & 2.8 \\
Radish & Leaf & 1.9 \\
Bean & Seed & 1.6 \\
Cotton & Root & 1.1 \\
Mung bean & Seed & 53.5 \\
Sunflower & Seed & 0.48 \\
Squash & Root & 6.2 \\
Spinach & Leaf & 1.3 \\
Turnip & Tuber & 1.1 \\
\hline
\end{tabular}

The key aim of this research is to assess the potential of different vegetables and their corresponding parts in absorbing $\mathrm{Cd}$ at various concentration levels within the Cd-enriched soils. The paper is concerned with growing edible vegetables in contaminated soil. However, the treatment of the contaminated soil is beyond the scope of this study. The findings will help to identify the most appropriate vegetable parts of selected vegetables for human consumption.

\section{Materials and Methods}

\subsection{Site Description}

The research was conducted in the Varamin Valley near Tehran. This is an agricultural area producing about $40 \%$ of Tehran's crop needs according to the authors' estimation. At the first stage of the experiment, an appropriate experimental farm site, which includes essential facilities such as water, electricity and a proper protection to prevent animals and people from entering the site, was selected.

The experiments were carried out at the Abureyhan Campus of Tehran University located in the Varamin Valley (about $40 \mathrm{~km}$ south of Tehran). The maximum monthly rainfall in this region is about $40 \mathrm{~mm}$ in March compared to and less than $5 \mathrm{~mm}$ in July, representing minimum precipitation. The temperature varies between 25 and $37^{\circ} \mathrm{C}$ in July, which is known as the hottest month, and between 1 and $8{ }^{\circ} \mathrm{C}$ in January, which is usually the coldest month.

Soil with a texture and structure similar to the dominant soil texture and structure of the whole region, was collected by gathering soil samples from different parts of the Abureyhan Campus. In order to avoid contaminating the soil samples utilized in the experiments and the entire experimental site, planting pots with a diameter and height of $80 \mathrm{~cm}$ and $100 \mathrm{~cm}$, respectively, were located in a vegetable farm area of about $1000 \mathrm{~m}^{2}$. The soil texture comprised silt (42\%), sand $(35 \%)$ and clay $(23 \%)$. The soil was almost neutral $(\mathrm{pH}=7.4)$ with a background $\mathrm{Cd}$ concentration of $0.03 \mathrm{mg} / \mathrm{kg}$ (Table 2). 
Table 2. Physical and chemical characteristics of soil samples (meq/L, milliequivalent of solute per litre).

\begin{tabular}{ccc}
\hline Variable & Unit & Value \\
\hline Sand & $\%$ & 35 \\
Silt & $\%$ & 42 \\
Clay & $\%$ & 23 \\
Organic carbon & $\%$ & 1.25 \\
Phosphorus (available by plants) & $\mathrm{mg} / \mathrm{kg}$ & 3.2 \\
Total nitrogen & $\%$ & 0.04 \\
Potassium (available by plants) & $\mathrm{mg} / \mathrm{kg}$ & 105 \\
pH & - & 7.4 \\
Cation-exchange capacity & $\mathrm{meq} / 100 \mathrm{~g}$ & 11 \\
Cadmium & $\mathrm{mg} / \mathrm{kg}$ & 0.03 \\
Sodium & $\mathrm{meq} / \mathrm{L}$ & 2.72 \\
Magnesium & $\mathrm{meq} / \mathrm{L}$ & 3.31 \\
Calcium & $\mathrm{meq} / \mathrm{L}$ & 4.12 \\
Sulphate & $\mathrm{meq} / \mathrm{L}$ & 3.8 \\
Chloride & $\mathrm{meq} / \mathrm{L}$ & 3.32 \\
Bicarbonate & $\mathrm{meq} / \mathrm{L}$ & 3.2 \\
\hline
\end{tabular}

\subsection{Cultivation and Measurements}

All experiments were carried out under laboratory-like conditions using a factorial testing plan as part of the random block model design with four different treatments and three replicates to assess the influences of dissimilar Cd concentrations within soil samples on three plant parts (root, zone and stem) for seven vegetables (spinach, garlic, carrot, dill, tarragon, basil and broccoli) representative of a wide section of available vegetable plant species. The $\mathrm{Cd}$ concentration was the only variable parameter between these treatments to reduce noise in the findings, and to obtain statistically valid results. Details of the four treatments are presented in Table 3.

Due to the high variability of $\mathrm{Cd}$ in real wastewater and the presence of other contaminants, the effect of wastewater contaminated with $\mathrm{Cd}$ used for irrigation of soil was simulated by using soil already contaminated by $\mathrm{Cd}$. Therefore, cadmium nitrate was powdered and mixed entirely to gain a homogenous mixture, which was used to prepare soil samples with three different $\mathrm{Cd}$ concentrations (30, 60 and $120 \mathrm{mg} / \mathrm{kg}$; Table 3). Finally, to check for the uniformity of Cd concentrations at different levels of the prepared soil sample, various samples were taken and their $\mathrm{Cd}$ concentrations were analysed in the laboratory. It should be mentioned that the soil samples were collected from different levels of the soil column using stainless steel sampling tools and clean plastic buckets. Samples were immediately sent to the laboratory in clean standard soil containers.

Considering that real wastewater is highly variable in its chemical composition, groundwater, which is relatively stable in its composition and which is the dominant water resource in the Varamin Valley, was used as a substitute to irrigate the example vegetable species during the growing season. The groundwater had an electrical conductivity of $635 \mathrm{dS} / \mathrm{m}$. The chemical traits of the groundwater are shown in Table 4. The Penman-Monteith equation [13] was utilized to accurately determine the crops' water demand during different growth stages. 
Table 3. Characteristics of the studied treatments.

\begin{tabular}{ccc}
\hline Treatment number & Description & Comment \\
\hline 1 & Soil with $0 \mathrm{mg} / \mathrm{kg} \mathrm{cadmium}(\mathrm{Cd})$ & Control \\
2 & Soil with $30 \mathrm{mg} / \mathrm{kg} \mathrm{Cd}$ & None \\
3 & Soil with $60 \mathrm{mg} / \mathrm{kg} \mathrm{Cd}$ & None \\
4 & Soil with $120 \mathrm{mg} / \mathrm{kg} \mathrm{Cd}$ & None \\
\hline
\end{tabular}

Table 4. Chemical configurations of Varamin Valley groundwater (meq/L, milliequivalent of solute per litre).

\begin{tabular}{ccc}
\hline Variable & Unit & Value \\
\hline Electric conductivity & $\mathrm{dS} / \mathrm{m}$ & 635 \\
$\mathrm{pH}$ & - & 7.3 \\
Calcium & $\mathrm{meq} / \mathrm{L}$ & 3.2 \\
Magnesium & $\mathrm{meq} / \mathrm{L}$ & 3.8 \\
Sodium & $\mathrm{meq} / \mathrm{L}$ & 1.69 \\
Potassium & $\mathrm{meq} / \mathrm{L}$ & 0 \\
Carbonate & $\mathrm{meq} / \mathrm{L}$ & 0 \\
Bicarbonate & $\mathrm{meq} / \mathrm{L}$ & 3.64 \\
Sulphate & $\mathrm{meq} / \mathrm{L}$ & 2.87 \\
Chloride & $\mathrm{meq} / \mathrm{L}$ & 2.05 \\
Cadmium & $\mathrm{meq} / \mathrm{L}$ & 0 \\
\hline
\end{tabular}

Cultivation of the investigated species was done according to the local cropping schedule using pots. No pesticides and fertilizers were used during the cultivation season to eliminate their potentially problematic impact on the outcome of the research. Any weeds were removed manually if and when appropriate.

At the end of the cultivation season, different sections of the investigated crops (root, stem and leaf) were used to assess $\mathrm{Cd}$ accumulation within these plant parts. After cutting the samples, they were washed with distilled water. They were subsequently dried at $100{ }^{\circ} \mathrm{C}$ and then burnt to gain their ashes, which were put in $100 \mathrm{~mL}$ of aqua regia (3 parts in volume of $12 \mathrm{M} \mathrm{HCl}$ to 1 part of $16 \mathrm{M} \mathrm{HNO}_{3}$ ) and diluted (1 in 20) with distilled water. Finally, the $\mathrm{Cd}$ concentrations were measured by graphite furnace atomic absorption spectroscopy (Perkins-Elmer model 4100ZL, Cupertino, CA, USA) for the prepared crop samples [12].

\subsection{Statistical Analysis}

An analysis of variance (ANOVA) was carried out on the data obtained from the measurements to analyse the differences between group means and their associated procedures such as the variation among and between groups. The observed variance in a particular variable was partitioned into components that can be attributed to various sources of variation. The ANOVA was used to assess whether or not the means of several groups were equal, and to compare at least three means of group or variables for statistical significance.

The common software package IBM SPSS Statistics was used. Moreover, the results obtained from the data analysis were then statistically compared with each other using the Duncan's Multiple Range test at $1 \%$ and $5 \%$ probably levels. This multi-comparison procedure provides significance levels for 
the difference between any pair of means. For graphical representation, common Microsoft Excel software was used.

\section{Results and Discussion}

\subsection{Effect of Species on Cadmium Accumulation}

The ANOVA table for Cd accumulation levels in different parts of the vegetables is presented in Table 5. The findings were significant at 0.01 probability level for all plant parts. It follows that it would make sense to distinguish between different vegetables and associated plant parts when regulating the agricultural market regarding contaminated products in the future.

Table 5. Variance analysis of the investigated characteristics in studied species.

\begin{tabular}{|c|c|c|c|c|}
\hline \multirow{2}{*}{ Sources of variation } & \multirow{2}{*}{ Degrees of freedom } & \multicolumn{3}{|c|}{ Mean square (MS) } \\
\hline & & Stem & Leaf & Root \\
\hline Species (S) & 6 & $15.14 * *$ & $4.98 * *$ & $4.13^{* *}$ \\
\hline Treatment $(\mathrm{T})$ & 3 & $51.32 * *$ & $30.143 * *$ & $15.16^{* *}$ \\
\hline $\mathrm{S} \times \mathrm{T}$ & 18 & $2.36^{* *}$ & $0.627 * *$ & $0.373^{* *}$ \\
\hline Error & 56 & 0.07 & 0.021 & 0.007 \\
\hline Coefficient of variation & not applicable & 15.72 & 10.68 & 8.85 \\
\hline
\end{tabular}

Note: **Significant at 0.01 probability level.

Cadmium pollution in water and soil has been a great challenge for a long time, and several suggestions regarding the maximum allowable concentrations have been recommended in the literature $[9,14,15]$. In addition to these recommendations, some standards have been presented concerning permissible $\mathrm{Cd}$ accumulations in various herbs, concentrations in sewage used for irrigation of farm land and human diet. A few representative and relevant maximum threshold recommendations are tabulated in Table 6.

Table 6. Maximum allowable concentrations of cadmium $(\mathrm{Cd})$.

\begin{tabular}{cccc}
\hline Organization & Reference & Maximum Cd & Application threshold \\
\hline World Health Organization & {$[16]$} & $0.1 \mathrm{mg} / \mathrm{L}$ & Drinking water \\
American Food Industries & {$[17]$} & $92 \mu \mathrm{g} / \mathrm{day}$ & Solid food intake \\
United States Environmental & {$[17]$} & $85 \mathrm{ppm}$ & Ooze deposition onto \\
Protection Agency & {$[18]$} & $7 \mu \mathrm{g} / \mathrm{kg}$ of body weight & farm land \\
United Nations & {$[18$ Solid food intake } \\
\hline
\end{tabular}

Cadmium concentrations for the tested vegetable species are presented in Table 7. The maximum concentration of $\mathrm{Cd}$ within leaves, stems and roots were always associated with broccoli. The corresponding minimum concentrations were linked to dill, dill and tarragon, respectively. However, the root concentration for dill was also relatively low.

\subsection{Effect of Treatment on Cadmium Accumulation}

The effect of different $\mathrm{Cd}$ concentrations in soil samples on the corresponding $\mathrm{Cd}$ accumulation level of the selected vegetables is presented in Figure 1. The highest amount of Cd concentration 
corresponds usually to leaves, while the lowest amount of $\mathrm{Cd}$ concentration has been determined for the roots. This poses a problem for those vegetables such as broccoli, spinach and basil where the leaves are consumed by humans and not the roots. On the other hand, a relatively low root contamination is advantageous for vegetables such as carrots where the roots are eaten by consumers.

Table 7. Average cadmium $(\mathrm{Cd})$ concentrations for the studied dried plants.

\begin{tabular}{cccc}
\hline \multirow{2}{*}{ Species } & \multicolumn{3}{c}{ Cd concentration $(\mathbf{m g} / \mathbf{k g})$} \\
\cline { 2 - 4 } & Leaf & Stem & Root \\
\hline Carrot & 2.67 & 1.28 & 1.83 \\
Tarragon & 2.51 & 1.68 & 0.71 \\
Basil & 3.23 & 1.96 & 1.98 \\
Garlic & 2.82 & 1.94 & 2.16 \\
Broccoli & 4.25 & 3.21 & 2.52 \\
Spinach & 3.54 & 2.47 & 1.86 \\
Dill & 1.83 & 1.03 & 0.84 \\
\hline
\end{tabular}

Figure 1. Comparison of the mean total cadmium $(\mathrm{Cd})$ concentrations for different parts of the vegetables and for different treatments (1: $0 \mathrm{mg} / \mathrm{kg} \mathrm{Cd} ; 2: 30 \mathrm{mg} / \mathrm{kg} \mathrm{Cd} ; 3: 60 \mathrm{mg} / \mathrm{kg} \mathrm{Cd}$; 4: $120 \mathrm{mg} / \mathrm{kg} \mathrm{Cd})$.

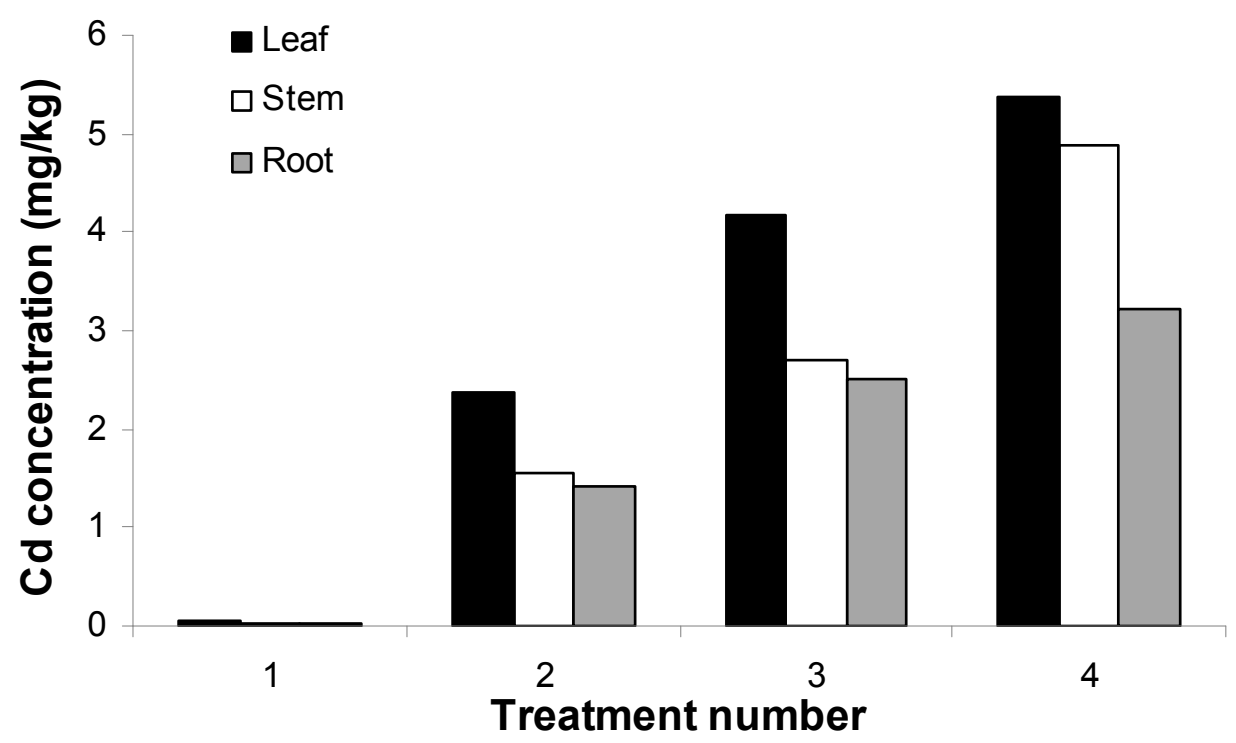

Table 8 compares the responses of different plant parts to various $\mathrm{Cd}$ treatments, indicating that the accumulated $\mathrm{Cd}$ is the highest for the fourth treatment (Table 3). Moreover, there is a direct positive correlation relationship between $\mathrm{Cd}$ concentration levels in all plant organs of the tested vegetables and the $\mathrm{Cd}$ concentrations in soil, simulating previously irrigated land with wastewater containing high levels of $\mathrm{Cd}$. It follows that a continuation of the historic practice of irrigation with wastewater needs to be regulated to prevent further permanent soil contamination.

The Cd accumulation results can be summarized as follow: Leaves; broccoli $>$ spinach $>$ basil $>$ garlic $>$ carrot $>$ tarragon $>$ dill. Stems: broccoli $>$ spinach $>$ basil $>$ garlic $>$ tarragon $>$ carrot $>$ dill. Roots: broccoli $>$ garlic $>$ basil $>$ spinach $>$ carrot $>$ dill $>$ tarragon. These relationships are useful when deciding on what vegetables to grow in the future. 
Table 8. Comparison of $\mathrm{Cd}$ concentrations $(\mathrm{mg} / \mathrm{kg})$ within different plant parts as a response to various cadmium $(\mathrm{Cd})$ treatments (Table 3 ). Sample number $\mathrm{n}=3$.

\begin{tabular}{|c|c|c|c|c|c|c|c|}
\hline \multirow{2}{*}{ Species } & \multirow{2}{*}{ Treatment } & \multicolumn{3}{|c|}{ Mean } & \multicolumn{3}{|c|}{ Standard deviation } \\
\hline & & Leaf & Stem & Root & Leaf & Stem & Root \\
\hline \multirow{4}{*}{ Carrot } & Treatment 1 & 0.053 & 0.026 & 0.037 & 0.020 & 0.004 & 0.006 \\
\hline & Treatment 2 & 2.136 & 1.024 & 1.464 & 0.942 & 0.295 & 0.451 \\
\hline & Treatment 3 & 3.738 & 1.792 & 2.562 & 0.939 & 0.625 & 0.955 \\
\hline & Treatment 4 & 4.806 & 2.304 & 3.294 & 0.961 & 0.406 & 0.403 \\
\hline \multirow{4}{*}{ Tarragon } & Treatment 1 & 0.050 & 0.034 & 0.014 & 0.010 & 0.012 & 0.002 \\
\hline & Treatment 2 & 2.008 & 1.344 & 0.566 & 0.230 & 0.44 & 0.130 \\
\hline & Treatment 3 & 3.514 & 2.352 & 0.990 & 0.606 & 0.901 & 0.056 \\
\hline & Treatment 4 & 4.518 & 3.024 & 1.273 & 1.106 & 1.563 & 0.055 \\
\hline \multirow{4}{*}{ Basil } & Treatment 1 & 0.065 & 0.039 & 0.042 & 0.013 & 0.009 & 0.025 \\
\hline & Treatment 2 & 2.584 & 1.568 & 1.586 & 0.198 & 0.254 & 0.225 \\
\hline & Treatment 3 & 4.522 & 2.744 & 2.776 & 1.161 & 0.829 & 0.731 \\
\hline & Treatment 4 & 5.814 & 3.528 & 3.569 & 0.796 & 1.098 & 1.190 \\
\hline \multirow{4}{*}{ Garlic } & Treatment 1 & 0.056 & 0.039 & 0.043 & 0.010 & 0.011 & 0.011 \\
\hline & Treatment 2 & 2.256 & 1.552 & 1.728 & 0.568 & 0.350 & 0.585 \\
\hline & Treatment 3 & 3.948 & 2.716 & 3.024 & 1.063 & 1.631 & 0.225 \\
\hline & Treatment 4 & 5.076 & 3.492 & 3.888 & 1.844 & 0.747 & 0.982 \\
\hline \multirow{4}{*}{ Broccoli } & Treatment 1 & 0.085 & 0.064 & 0.051 & 0.020 & 0.021 & 0.013 \\
\hline & Treatment 2 & 3.400 & 2.568 & 2.568 & 1.198 & 0.601 & 0.759 \\
\hline & Treatment 3 & 5.950 & 4.494 & 4.494 & 1.805 & 1.103 & 0.630 \\
\hline & Treatment 4 & 7.650 & 5.778 & 5.778 & 2.141 & 0.799 & 1.264 \\
\hline \multirow{4}{*}{ Spinach } & Treatment 1 & 0.071 & 0.049 & 0.037 & 0.011 & 0.013 & 0.006 \\
\hline & Treatment 2 & 2.832 & 1.976 & 1.488 & 0.699 & 0.871 & 0.358 \\
\hline & Treatment 3 & 4.956 & 3.458 & 2.604 & 1.888 & 0.777 & 0.438 \\
\hline & Treatment 4 & 6.372 & 4.446 & 3.348 & 0.808 & 0.518 & 0.936 \\
\hline \multirow{4}{*}{ Dill } & Treatment 1 & 0.030 & 0.021 & 0.017 & 0.011 & 0.008 & 0.002 \\
\hline & Treatment 2 & 1.464 & 0.824 & 0.672 & 0.477 & 0.226 & 0.338 \\
\hline & Treatment 3 & 2.562 & 1.442 & 1.176 & 0.723 & 0.568 & 0.375 \\
\hline & Treatment 4 & 3.294 & 1.854 & 1.512 & 0.891 & 0.911 & 0.198 \\
\hline
\end{tabular}

The simulated treatments are representative of future soil conditions if the practice of using irrigation wastewater containing $\mathrm{Cd}$ is not discontinued. The evaluation of vegetable responses to each treatment may lead to an informed decision about future plant selection. Table 8 indicates that dill and tarragon are possibly the best planting options in contrast to broccoli, which planting should not be encouraged anymore.

\subsection{Consequences of Findings}

The $\mathrm{Cd}$ accumulations in the selected plant species exceeded the permissible limit $(0.5 \mathrm{mg} / \mathrm{kg}$ as discussed by [9]) for human food intake. It follows that the studied example vegetables should not be consumed anymore. This could be regulated for the agricultural industry. However, small farmers and 
poor families who support their diet with food grown in their garden are likely to continue producing and eating contaminated vegetables due to economic pressure.

Cultivating vegetables on farms where the $\mathrm{Cd}$ concentration in the corresponding soil is more than $30 \mathrm{mg} / \mathrm{kg}$ leads to $\mathrm{Cd}$ accumulations in vegetables likely to exceed existing permissible thresholds recommended for human consumption. This is the case for large areas of the case study region, and representative for other countries in North Africa and the Middle East.

In areas where the soil is heavily contaminated due to decades of wastewater application and where wastewater is the only available and economic water source, farmers have either the option to continue farming and to produce contaminated crops or to stop farming. A political decision needs to be made by the responsible authorities to come to a realistic solution that does not harm public health and agricultural exports. Subsidies for the installation of (better) wastewater treatment systems and soil remediation programmes might be an option for oil-rich countries such as Iran. In contrast, economically poor countries in the same region such as Yemen and Jordan might not be able to afford potentially expensive treatment systems [1,2]. However, there is well-established guidance on how to irrigate farms with treated wastewater in a sustainable manner without undertaking expensive land remediation programmes [19].

\subsection{Limitations}

Uncontaminated soil to which increasing concentrations of $\mathrm{Cd}$ was added was used in this experiment. Alternatively, freshwater spiked with different $\mathrm{Cd}$ concentrations could have been used. This would have resulted in long-term accumulation of Cd. However, it would have taken many years to reach the desired concentrations within the soil before the experiment could have been started. Moreover, $\mathrm{Cd}$ is easily adsorbed by clay located within the soil matrix, which makes the argument for long-term adsorption less relevant.

The usefulness of the findings is limited to arid countries where irrigation with heavy metal-enriched wastewater has been practiced for many years or even decades. However, the study is also relevant for countries wishing to recycle wastewater for irrigation in the future. They could learn from the mistakes of those countries with contaminated soil due to poor irrigation strategies.

A further limitation is the lack of a high number of replicates. Three replicates were assessed in Table 8 . The findings would have been more significant if at least 30 replicates would have been used. However, there were resource restrictions in terms of work force and funding.

\section{Conclusions and Recommendations}

Wastewater recycling for the irrigation of crops is a possibility for countries with low freshwater availability. However, studies have shown that relatively high concentrations of $\mathrm{Cd}$ in soil samples resulted in high $\mathrm{Cd}$ accumulations in plant parts. The maximum average $\mathrm{Cd}$ concentrations of 4.25 , 3.12 and $2.52 \mathrm{mg} / \mathrm{kg}$ were observed in leaves, stems and roots of broccoli, respectively. There is a positive correlation between the amount of $\mathrm{Cd}$ in soil samples and its accumulation in plant parts. Considering that most of the selected plants such as broccoli and spinach absorbed and accumulated relatively high $\mathrm{Cd}$ quantities in their stems and leaves, which are consumed by humans, it is recommended to prevent cultivation of these vegetables on farm lands, which are irrigated with 
essentially untreated urban and industrial wastewater containing high levels of heavy metals such as $\mathrm{Cd}$. Moreover, vegetables should not be grown on farm land, which has already a Cd concentration of more than $30 \mathrm{mg} / \mathrm{kg}$.

The authors recommend the reuse of treated wastewater to irrigate farm lands in the future. This should result in edible vegetables. Treatment technology such as integrated vertical-flow constructed wetlands might offer a cost-effective and sustainable solution.

\section{Acknowledgments}

The authors thank Tehran University for provision of experimental facilities and Bahman Yargholi (Agricultural Engineering Research Institute, Karaj, Iran) for advice. The collaborative work would not have been possible without the support of the University of Delaware and The University of Salford.

\section{Author Contributions}

Babak Bakhshayesh and Madjid Delkash undertook the experimental work. Miklas Scholz wrote the article based on a first draft paper provided by Madjid Delkash.

\section{Conflicts of Interest}

The authors declare no conflict of interest.

\section{References}

1. Almas, A.A.M.; Scholz, M. Potential for wastewater reuse in irrigation: Case study from Aden (Yemen). Int. J. Environ. Stud. 2006, 63, 131-142.

2. Almas, A.A.M.; Scholz, M. Agriculture and water resources in Yemen: Need for sustainable agriculture. J. Sustain. Agric. 2006, 28, 55-75.

3. Mohammadi, Y.; Sabouhi, M. Analysis of effective components on agricultural water management in Zarindasht County from farmers viewpoint. J. Agric. Sci. Nat. Resour. 2009, 16, 9-18. (In Persian)

4. Brooks, D.B. An operational definition of water demand management. Int. J. Water Resour. Dev. 2006, 23, 227-241.

5. Rezadoost, B.; Allahyari, M.S. Farmers opinions regarding effective factors on optimum agricultural water management. J. Saudi Soc. Agric. Sci. 2013, 13, 15-21.

6. Hashem, H.A.; Hassanein, R.A.; Shouman, A.I. Irrigation with industrial wastewater activates antioxidant system and osmoprotectant accumulation in lettuce, turnip and tomato plants. Ecotoxicol. Environ. Safety 2013, 95, 144-152.

7. Torabian, A.; Mahjouri, M. Heavy metals uptake by vegetable crops irrigated water in south Tehran. J. Environ. Study 2002, 16, 34. (In Persian)

8. Harati, M.; Varavi Pour, M.; Tamadon Rastegar, M.; Foghi, B. Effect of urban wastewater usage and problems of accumulation of heavy metals in agricultural lands (south of Tehran). Afr. J. Agric. Res. 2011, 6, 3224-3231. 
9. Miller, R.W.; Al-Khazraji, M.L.; Sisson, D.R.; Gardiner, D.T. Alfalfa growth and absorption of cadmium and zinc from soils amended with sewage sludge. Agric. Ecosyst. Environ. 1994, 23, $33-45$.

10. Arona, M.; Kiran, B.; Rani, S.; Rani, A.; Kaur, B.; Mittal, N. Heavy metal accumulation in vegetables irrigated with water from different sources. Food Chem. 2008, 111, 811-815.

11. Hashemi, S.A. The investigation of irrigation with wastewater on trees (Populus deltoids L.). Toxicol. Ind. Health 2013, 29, 711-715.

12. Izadiyar, M.H.; Yargholi, B. Study of cadmium absorption and accumulation in different parts of four forages. Am. Eurasian J. Agric. Environ. Sci. 2010, 9, 231-238.

13. Monteith, J.L. Evaporation and environment. Symp. Soc. Exp. Biol. 1965, 19, 205-224.

14. Okoronkwo, N.E.; Igwe, J.C.; Onwuchekwa, E.C. Risk and health implications of polluted soils for crop production. Afr. J. Biotechnol. 2005, 4, 1521-1524.

15. Kabatta, A.; Pendis, H. Trace Elements in Soils and Plants, 3rd ed.; CRC Press: Boca Raton, FL, USA, 1992.

16. Sauerbeck, D.R. Uptake and bioavailability of heavy metals. J. Water Air Soil Pollut. 1991, 57-58, $227-237$.

17. United States Environmental Protection Agency. Process Design Manual: Land Application of Sewage Sludge and Domestic Sewage; Office of Research and Development: Washington, DC, USA, 1995.

18. Ernst, A. Bioavailability of Heavy Metals and Decontaminations of Soils by Plants; World Health Organization: Geneva, Switzerland, 1996.

19. Food and Agriculture Organization. Users Manual for Irrigation with Treated Wastewater; Food and Agriculture Organization of the United Nations, Food and Agriculture Organization Regional Office of the Near East: Cairo, Egypt, 2003.

(C) 2014 by the authors; licensee MDPI, Basel, Switzerland. This article is an open access article distributed under the terms and conditions of the Creative Commons Attribution license (http://creativecommons.org/licenses/by/3.0/). 